\title{
Human Resource Management for Vocational Schools at Bac Ninh Province, Vietnam: A Model Faculty Development Program
}

\author{
Nguyen Quoc Hieu - Peter: Bacninh College of Electromechanics and Construction, Vietnam.
}

\begin{abstract}
The study aimed to evaluate the "Human resource management for vocational schools at Bac Ninh province, Viet Nam: A model of faculty development program". It concentrated on evaluating the existing Human resource management for vocational schools of the province, determining the demographic profile of the respondents, profile of vocational schools. In order to come up with this analysis, a survey covering 50 specific vocational schools was implemented aiming to assess the current status of the development of contingent of teachers and the factors affecting the development of teaching staff for vocational schools in Bac Ninh province such as Human resource planning; recruitment and selection; Training and development Retention and maintenance; Promotion; Labor relations; and Transfer and retirement. Thereby, identifying the limitations in Human resource management of vocational schools. Based on all the findings of this study, the following conclusions were derived: The human resource management of vocational schools on Bac Ninh province was still limited. Human resources were in sufficient quantity, but the structure not to be reasonable, lack of highly qualified and experienced faculty. Support policies are not sufficient to motivate faculty and attract highly qualified human resources. From the cited summary of findings and conclusions, the following are hereby recommended: Re-examining all the plans and programs for the Quality of Human Resource so that necessary updating and modification can be done; Strongly focusing on the recruitment process and policies of training and retraining human resources, Specific strategies for implementing these plans must also be considered. Conducting regular evaluations of all the programs must be implemented.
\end{abstract}

Key words: Human resource management, Vocational schools, Faculty development program, Bac ninh province.

\section{Introduction}

Organizations and companies succeed, or fail, based on the quality and effectiveness of their employees. Human resource management (HRM), therefore, is the foundation, playing a vital role in the activities of the organizations because it can support other activities so that enable the organizations to survive and grow in competition these days (Abonam, 2011). The practice of HRM must be viewed through the prism of overall strategic goals for the organization instead of a standalone tint that takes a unit based or a micro approach. The idea here is to adopt a holistic perspective towards HRM that ensures that there are no piecemeal strategies and the HRM policy enmeshes itself fully with those of the organizational goals (Bianca, 2018).

In the field of vocational education, trainers keep the crucial role to ensure the quality of the training. Besides, vocational trainers are motivation and important factor to raise the capability of competition of human resoures in Vietnam. Law on Vocational Training (2006), provides for the organization and operation of vocational training institutions; rights and obligations of iners can be considered as "source" investment to develop of human resources. Capacity of vocational trainers is the decisive factor in the successful implementation of the proposed objectives of vocational training. Therefore, building and

Vol. 2, No.4, pp. 249-254

2019

Article History:

Revised: 25 September 2019

Published: 19 December 2019

(C) 2019 by the authors; licensee Academic

Publishing Group

$$
\text { | } 249
$$


developing the capacity of vocational trainers must be implemented at the same time by authorities and vocational training institutions. The most important thing is enhance professional knowledge, practicing skills, teaching skills, updating new technology and actual production for vocational trainers.

Bac Ninh is a province located in the Red River Delta of the northern part of Vietnam. The college was founded with mandates to train technical personnel directly in production, service meet the requirements of the labor market for Industrial parks in the province and surrounding areas. The vocational colleges in Bac Ninh province in the period of education reform, therefore, high quality human resources are needed, including people with specialist knowledge and professional skills. Moreover, in the trend of developing intellectual economy and globalizing the world economy, high quality human resources are considered as a condition to shorten the distance between being laged behind and rapid growth. But in fact, the vocational colleges's human resource now does not meet the requirements of the development. Hortage of quantily and quality of human resource is a great difficulty for college's survival and development, leading affect to the quality of graduates, decrease the number of students enrolled in the school annual. There are few basically trained teachers for some vocational training majors; their teaching skills are limited; there are also few teachers whose teaching is integrated compared with the requirements of the training program. The vocational teachers' ability of developing and editing vocational programs, curriculums, training materials is limited. Besides, foreign language and computer skills of vocational teachers are weak. As a result, it is limited the ability to update new technologies and the computerization of modern pedagogy. Therefore, the research and analysis of the organization's human resources management is really urgent in order to find out the solution to improve its human resource.

\section{Theoretical Background}

2.1. Human Resource

Human Resource is all the activities of an organization to attract, build, develop, use, evaluate, preserve and keep a force in accordance with the requirements of organizations both in quantity and quality of its employees (Nguyen, 2014). Most organization agree that human resource activities are valuable to their success and the efforts of its employees.

\subsection{Human Resource Development}

Human resource development is the framework for helping employees to develop their personal and organizational skills, knowledge, and abilities. It represents a broad vision of the relationship between individuals and society regarding their capabilities and capacities for sustainable economic development. However, when human resources development is directed towards a specific sector, in this case the public sector, the focus changes to a specific process of dealing with the attraction of people into, their retention in, and subsequent departure from that sector. At the organizational level, a successful Human Resources Development program prepares the individual to undertake a higher level of work, "organized learning over a given period of time, to provide the possibility of performance change" (Nadler, 1984). Kedzior and Fifield (2014), described effective professional development as a prolonged facet of classroom instruction that is integrated, logical and on-going and incorporates experiences that are consistent with teachers' goals; aligned with standards, assessments, other reform initiatives, and beset by the best research evidence. Elmore (2002), described professional development as sustained focus over time that is consistent with best practice.

\subsection{HRM at Vocational Schools}

According to the Vietnam Education Law in 1998, vocational training is a part of vocational education, including short-term vocational training (less than 1 year) and long-term vocational training (1-3 years). These two types of training are conducted at vocational schools and colleges. In addition, short-term vocational training is also carried out at vocational training centers. Since the Law on Vocational Training came into effect (since July 31, 2007), the system of policies to encourage vocational training has also been completed and developed, marking an important turning point in career development for workers. Two types of vocational training (short-term and long- term) are converted into vocational training at 3 levels: vocational college, vocational secondary school, vocational primary school and regular vocational training. Lecturers of vocational colleges are a collection of teachers who

\begin{tabular}{l} 
International Journal of Educational \\
Studies \\
Vol. 2, No.4, pp. 249-254 \\
2019 \\
DOI: 10.53935/2641-533x.v2i4.127 \\
Funding: This study received no specific \\
financial support. \\
Article History: \\
Received: 22 August 2019 \\
Revised: 25 September 2019 \\
Accepted: 30 October 2019 \\
Published: 19 December 2019 \\
() 2019 by the authors; licensee Academic \\
Publishing Group \\
\hline | 250
\end{tabular}




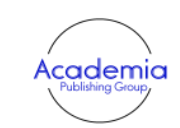

International Journal of Educational Studies

Vol. 2, No.4, pp. 249-254

2019

DOI: $10.53935 / 2641-533 x . v 2 i 4.127$

Funding: This study received no specific

financial support.

Article History:

Received: 22 August 2019

Revised: 25 September 2019

Accepted: 30 October 2019

Published: 19 December 2019

(C) 2019 by the authors; licensee Academic

Publishing Group

| 251 are responsible for teaching and scientific research in vocational colleges, and they work together to carry out vocational training tasks and objectives together teaching and educating students according to the constraints of administrative principles. Characteristics of vocational training is teaching practice which is mainly to form vocational skills for learners, so in the contingent of vocational college teachers, the number of integrated teaching teachers (theory and practice) and practice occupation occupies a larger number. In management, it is necessary to pay attention to developing a qualified and standard faculty of vocational colleges. Therefore, the development of the contingent of vocational colleges has a close relationship with the demand of training human resources of the society.

Vu-Anh (2015), expresses the insufficiency in training vocational teachers which leads to the situation that vocational teachers are not good at practical skills. Vietnamese General Department of Vocational Training has proposed the policy to assess practical skills vocational teachers to issue to them another certificate after they have been granted vocational training certificate. However, this issue has not taken into interest or there has not been sufficient solution for training teachers, vocational teachers. Through analysis and opinions of colleagues, the author also proposed a number of solutions in training vocational teachers and developing specific occupational skill standards for them in each field of different specific occupations. Thereby, each teacher and leader of training institutions must to compare, to be trained or update themselves to meet the necessary standards. Before evaluation, attention should be paid to training and retraining; develop criteria, standards and assessment methods appropriate to the specific time, nature and professional objectives of the target quality.

ReferNet (2009), gave a research of an overview of the Vocational education system in Spain. The paper overviewed the current arrangements for staff development activities for teachers in the Vocational Education and Training (VET) sector across Australia. The overview contained the results of a recent survey of staff development activities offered by universities and Departments of Education and Training in each State/Territories. The findings indicated a lack of consistency in minimum teaching qualifications of teachers/trainers and no apparent comprehensive database of staff development activities.

The use of the term staff development in the vocational education training sector includes professional development as well as training and development, suggesting little or no difference between the three. However, there are differences between the three in terms of the purpose of each (Mondy \& Noe, 2008). Mondy and Noe (2008), perceived the primary purpose of staff development is to improve efficiency and effectiveness. They refered to training as learning activities that enhance competencies to improve work performances. Teachers/trainers in the vocational education training sector acquire most of the teaching competencies during initial teacher training, however the development of additional skills is an on-going activity throughout their teaching/training career. Mondy and Noe (2008) define development as transformations in individuals resulting from social, cultural, technological and environmental changes. Such transformations are largely the outcomes of life experiences.

Many additional cases in which HRD supports the implementation of business strategy can be cited. Training and other initiatives associated with total quality management have been critical in transforming marginal manufacturing plants into successful facilities (Sullivan, 2009). HRD continues to be a primary vehicle for assuring mandated levels of employee competence and public safety in highly regulated sectors like the nuclear power industry (George \& Sabapathy, 2011). Several leading corporations consider the value added through state-of-the- art employee expertise so important to their operations that they have created extensive internal systems for providing education and training. Examples of these systems include the Texas Instruments Learning Institute, the Xerox Palo Alto Research Center, and Disney University (Brown, 1991; Jennifer \& Jean, 2009).

\section{Research Method}

The descriptive method was employed in this research. A questionnaire checklist was designed by the researcher to gather data from the respondents. The principal aims of this method is to describe the nature of the situation as it exists at the time of the research and explore the cause of the particular event. It involved collection of data to answer questions concerning the current status of the subject.The descriptive method of research is an appropriate method for determining impact of human resource management practices on the organizational performance of the colleges in Bac Ninh province through evaluation of respondents. Their responses evaluated the factors affecting the development of teaching 
staff for vocational schools in Bac Ninh province and propose a model faculty development program for vocational college in Bac Ninh province. Both primary and secondary data are used in this study. Primary data were gathered from a survey of 50 vocational training institutions in Bac Ninh Province Viet Nam. Secondary data are sourced from various government agencies, a number of publications, and education associations. The researcher used the questionnaire as the main instrument for data gathering. The questionnaire was collated in groups and ranked on five-point type scale to measure the perception of respondents on the employees' HRM practices of the vocational training institutions in Bac Ninh. The self-made questionnaire was tested and validated by experts. This was used as primary data collection device.

\section{Research Results and Suggestion of a Faculty Development Program}

This research studies the data collected through primary and secondary sources. It includes the findings in respect of profile of respondents, Human Resource Planning, Recruitment, Selection, Training and development, Performance Appraisal, Promotion, Retention and maintenance. Based on the results to propose possible solutions could be introduced to human resource development program for vocational schools in Bac Ninh province.

\begin{tabular}{llll}
\multicolumn{4}{c}{ Table-1. Type and level of vocational centers in Bac Ninh province } \\
\hline $\begin{array}{l}\text { Vocational } \\
\text { institutions }\end{array}$ & training & $\begin{array}{l}\text { Number of vocational } \\
\text { college }\end{array}$ & Teaching staff \\
\hline Vocational college & 6 & 329 \\
Vocational & secondary & 12 & 369 \\
schools & & & \\
Vocational training centers & 20 & 523 \\
$\begin{array}{l}\text { Other vocational } \\
\text { institutions }\end{array}$ & training & 12 & 219 \\
Total & & & \\
\hline
\end{tabular}

There are 50 vocational schools in Bac Ninh province, including: Vocational college 6 schools; Vocational secondary schools 12 schools; Vocational training centers 20; Other vocational training institutions 12. And total 1440 teachers Table 1.

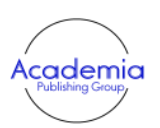

International Journal of Educational Studies

Vol. 2, No.4, pp. 249-254

2019

DOI: $10.53935 / 2641-533 x . v 2 i 4.127$ Funding: This study received no specific financial support.

Article History:

Received: 22 August 2019

Revised: 25 September 2019

Accepted: 30 October 2019

Published: 19 December 2019

(c) 2019 by the authors; licensee Academic

Publishing Group
Table-2. Mean Distribution of Respondents' Perception on the HRM

\begin{tabular}{|c|c|c|c|c|c|c|}
\hline \multirow{2}{*}{ Factors (Variables) } & \multicolumn{2}{|c|}{ Teachers } & \multicolumn{2}{|c|}{ Managers } & \multicolumn{2}{|c|}{ Weight mean } \\
\hline & Mean & QI & Mean & QI & Mean & QI \\
\hline $\begin{array}{l}\text { 1. Human resource } \\
\text { planning }\end{array}$ & 3.44 & Good & 3.56 & Good & 3.50 & Good \\
\hline $\begin{array}{l}\text { 2. Recruitment and } \\
\text { selection }\end{array}$ & 3.05 & Fair & 3.27 & Fair & 3.16 & Fair \\
\hline $\begin{array}{l}\text { 3. Trainning and } \\
\text { development }\end{array}$ & 2.56 & Poor & 2.83 & Fair & 2.70 & Fair \\
\hline 4. Retention and & 2.71 & Fair & 2.93 & Fair & 2.82 & Fair \\
\hline maintenance & & & & & & \\
\hline 5. Promotion & 3.24 & Fair & 3.13 & Fair & 3.19 & Fair \\
\hline 6. Labor relations & 2.71 & Fair & 2.99 & Fair & 2.85 & Fair \\
\hline $\begin{array}{l}\text { 7. Transfer and } \\
\text { retirement }\end{array}$ & 3.56 & Good & 3.86 & Good & 3.71 & Good \\
\hline AVERAGE & 3.04 & Fair & 3.22 & Fair & 3.13 & Fair \\
\hline
\end{tabular}

According to Table 2, Perception of the Respondents, who are teachers and managers is both at the Average level. Of which, the factors of Human resource planning and Transfer and Retirement are rated at Good level. The item "Training and Development" at vocational schools was rated at Poor level based on the response of Teachers. Meanwhile, for teachers in vocational schools, training and development 
issues to improve skills, applying theory to practice for them is one of the most important factors. This result shows that, in human resource management of vocational schools in Bac Ninh province, the issue of human resource training and development is still underestimated and not yet paid fully attention. This is one of the issues that human resources managers need to care about and improve.

The test for non-significant difference between their responses reveals a computed $\mathrm{t}$ Stat = $0.91152<$ t Critical two-tail $=2.178813$, which means that the null hypothesis is accepted. The difference among responses is not significant.

Table-3. Propose a model faculty development program

\begin{tabular}{l|l|l}
\hline t-Test: Two-Sample Assuming Unequal Variances \\
\hline & Manager & Staff \\
Mean & 3.038571 & 3.224286 \\
Variance & 0.153114 & 0.137462 \\
Observations & 7 & 7 \\
Hypothesized Mean Difference & 0 & \\
Df & 12 & \\
t Stat & -0.91152 & \\
P(T<=t) one-tail & 0.189985 & \\
t Critical one-tail & 1.782288 & \\
P(T<t) two-tail & 0.37997 & \\
t Critical two-tail & 2.178813 & \\
\hline
\end{tabular}

Since the specific items under each indicator variables were patterned from a written reference, the researcher considered this as standards, so those item rated by the respondents relating to the existing human resource management practice at the vocational colleges currently implemented served as the actual, and whatever items which will not comply high with the standards (those rated below "Good") could be regarded as the gap that could require further improvement.

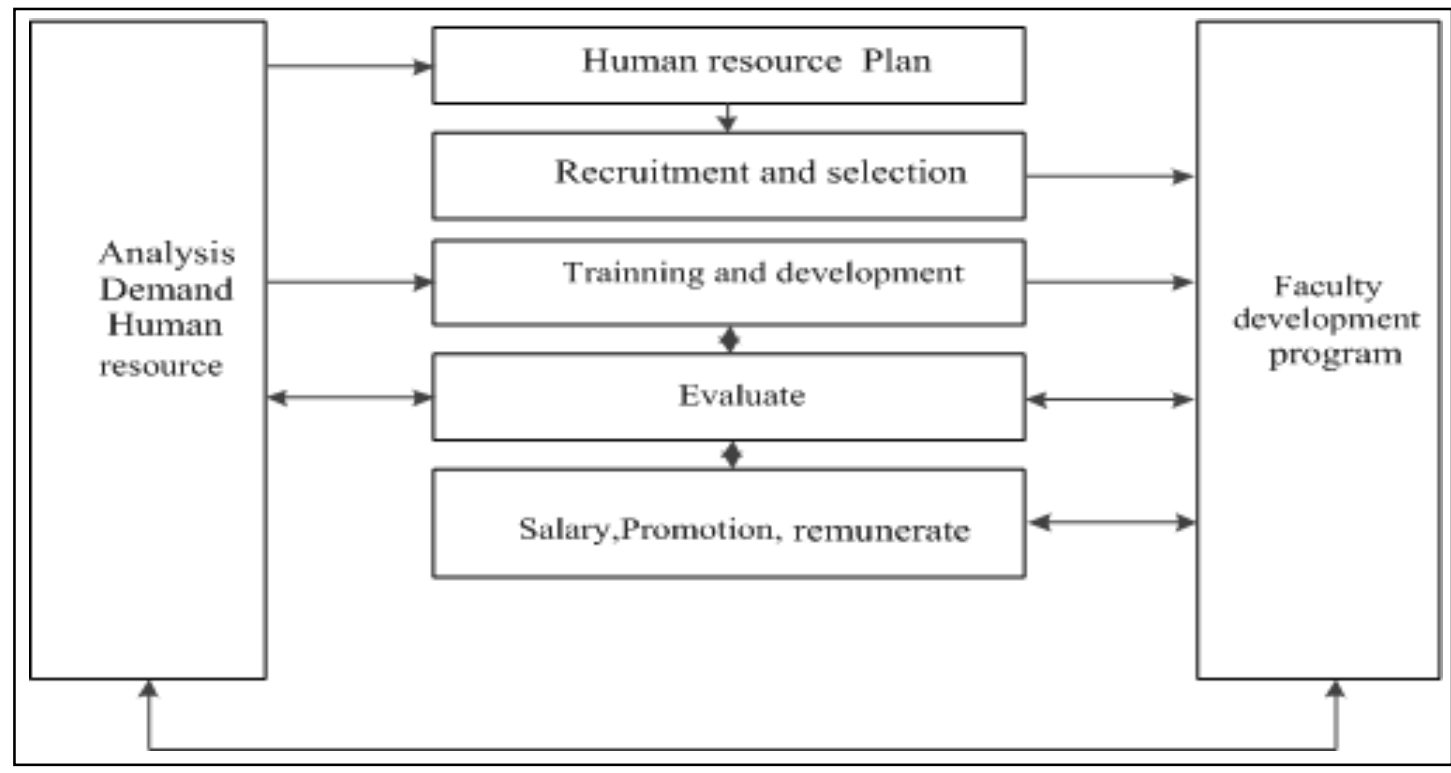

Figure-1. T-Test: Two-Sample Assuming Unequal Variances

The program need to determine the targets of College and analysis of human resources needs. It is necessary to built suitable plan to human resource recruitment and selection, tranning and development; evaluating the performance of the work of the teachers; building remuneration, welfare, fines policies.

It is needed to improve the capacity of teaching staff, renovate the training program in the direction of enhancing the practice of practice, attaching importance to raising the quality of pedagogical training for students, renewing the method of training teachers. The next task is further develop the professional 


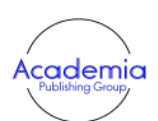

International Journal of Educational Studies

Vol. 2, No.4, pp. 249-254

2019

DOI: $10.53935 / 2641-533 x . v 2 i 4.127$

Funding: This study received no specific

financial support.

Article History:

Received: 22 August 2019

Revised: 25 September 2019

Accepted: 30 October 2019

Published: 19 December 2019

(C) 2019 by the authors; licensee Academic

Publishing Group

254 capacity, continue the implementation of appropriate remuneration policies for teachers to well perform the task of fostering and retraining lecturers. Inviting key teaching universities for training courses is required. It is necessary to arrange for teachers to take turns to improve their knowledge and cooperate with pedagogical schools or invite experts and qualified lecturers to directly train teachers. Along with that, promote the activities of professional activities (through time, lectures ...) in clusters, inter-school to create a forum for teachers to share, learn experience and self-enrich each other. Renovating the work of planning and revising and supplementing regulations on recruitment of trainers; Developing policies to attract experts and engineers in the technical department with high professional qualifications of the companies participating in the training institutions. Regularly organizing soft skills training for faculty members: teaching as well as any other work that needs soft skills such as communication skills, presentation skills, creative skills. Especially the investment to train engineers, specialists, bachelors and technicians with high professional qualifications, being in full knowledge of computer science, foreign languages and the skills necessary (operational skills, communication skills, and life skills); capable of thinking, capacity for cooperation and competition have the ability to learn to improve themselves; comprehensive development of intellectual, physical, moral and cultural; Qualified teachers, the number of lecturers corresponding to the number of students as prescribed.

\section{Conclusion}

Based from all the findings of this study, the following conclusions were derived: The human resource management of vocatinal schools on Bac Ninh province still limited. Human resources in sufficient quantity, but the structure is not reasonable. Lack of highly qualified and experienced faculty. Support policies are not sufficient to motivate faculty and attract highly qualified human resources. Therefore, a model faculty development program was proposed in order to give recommendation and suggestion for policies' makers and administrators of the vocational schools in Bac Ninh province, Vietnam.

\section{References}

Abonam, N. D. (2011). The role of motivation on employee performance in the public sector: A case study of the university for development studies, Wa campus. Thesis, Institute of Distance Learning, Kwame Nkrumah University of Science and Technology, in Partial Fulfillment of the Requirement for the Degree Bachelor of Arts.

Bianca. (2018). The role of human resource management in organizations. Retrieved from: http://smallbusiness.chron.com/role-human-resource-management-organizations-21077.html.

Brown. (1991). An alternative for exiting the deviant career. Retrieved from: https://onlinelibrary.wiley.com/doi/pdf/10.1111/j.1533-8525.1991.tb00354.x.

Elmore. (2002). Bridging the gap between standards and achivement: Albert Shannker Institute Publishing.

George, L., \& Sabapathy, T. (2011). Work motivation of teachers: Relationship with organizational commitment. Canadian Social Science, 7(1), 90-99.

Jennifer, T., \& Jean, G. (2009). Organizational approaches to flexible working: Perspectives of equality and diversity managers in the UK. Equal Opportunities International, 28(8), 671. Available at: http://dx.doi.org/10.1108/02610150911001706.

Kedzior, \& Fifield. (2014). Education policy brief. Teacher Professional Development.

Law on Vocational Training. (2006). Dated 29 month 11 year 2006. And law on vocational education, 74/2014/qh13. Dated november 27, 2014.

Mondy, \& Noe. (2008). Human resource management (10th ed.): Pearson.

Nadler. (1984). The handbook of human resource development. Hoboken, NJ: John Wiley and Sons.

Nguyen, V. D. (2014). Human resource management: National economics (2nd ed.). Vietnam: University Publishing House.

ReferNet. (2009). The vocational education and training system of cyprus: A thematic overview.

Sullivan. (2009). Academic self-concept, Gender and single-sex schooling. Retrieved from: https://onlinelibrary.wiley.com/doi/full/10.1080/01411920802042960.

Vu-Anh, D. (2015). Some teacher practice skills issues of vocational teachers. Ninh Binh: Mechanical College Publishing. 